\title{
Towards an Integrated Model of Customer Religiosity: A Self-Determination Theory Perspective
}

\author{
Faheem Gul Gilal ${ }^{1}$, Abdul Khalique Gadhi², Rukhsana Gul Gilal ${ }^{3}$, \\ Naeem Gul Gilal ${ }^{4}$, Na Zhang ${ }^{5}$, Zhenxing Gong ${ }^{6}$
}

Submitted: 25.01.20. Accepted: 7.06.20

\section{Abstract}

Purpose: Drawing on self-determination theory (SDT), this article aims to examine the impact of customers' intrinsic and extrinsic religiosity on purchase intentions for luxury brands. Moreover, this study delves into the moderating effect of customer brand loyalty in these relationships.

Methodology: To this end, we tested our hypotheses with a student sample $(N=169)$ from Pakistan. Exploratory factor analysis (EFA), confirmatory factor analysis (CFA), structural equation modeling (SEM), and moderation analysis techniques were used to analyze the data using SPSS 24.0 and AMOS 24.0.

Findings: The results of data analysis indicated that a customer's purchase intention for luxury brands is significantly influenced by extrinsic religiosity, while intrinsic religiosity has trivial influence in boosting purchase intention for a luxury brand. Our results for moderation analysis further show that customer purchase intention for a luxury brand is reinforced by intrinsic religiosity when customer brand loyalty is high but not when customer brand loyalty is low, whereas purchase intention for a luxury brand is fortified more by extrinsic religiosity when customer brand loyalty is low than when customer brand loyalty is high.

Research Limitations: As with any set of cross-sectional studies, our research is not without limitations. For instance, the sample size in the current study is purposefully small. This limits the generalizability of findings across a wider population.

Implications/originality/value: This study has provided a framework to explain how customers' intrinsic and extrinsic religiosity affected the purchase intentions of luxury brands in the emerging market.

Keywords: intrinsic religiosity, extrinsic religiosity, luxury purchase intention, customer brand loyalty

JEL: M31

\footnotetext{
Department of Business Administration, Sukkur IBA University, Airport Road, Sukkur Sindh, Pakistan; e-mail: faheemgulgilal@yahoo.com; https://orcid.org/0000-0002-7635-7642.

2 Department of Business Administration, Sukkur IBA University, Airport Road, Sukkur Sindh, Pakistan; e-mail: abdulkhalique.gadhi@gmail.com.

3 Department of Business Administration, Sukkur IBA University, Sukkur, Sindh, Pakistan; e-mail: rukhsanagulgilal@yahoo.com; https:// orcid.org/0000-0001-7475-3097.

4 School of Management, Huazhong University of Science and Technology, 1037 Luoyu Rd, Hongshan, Wuhan, Hubei, China, 430074; e-mail: naeemgulgilal@yaho0.com; https://orcid.org/0000-0001-8761-3093.

5 School of Economics and Management, Beijing Information Science \& Technology University, Beijing, China; e-mail: b15033@buaa.edu.cn; https://orcid.org/0000-0001-8361-5411.

6 School of Business, Liaocheng University, No.1 Hunan Road, Liaocheng City, Shandong Province, China; e-mail: zxgong118@163.com; https://orcid.org/0000-0002-2781-7577.
} 


\section{Introduction}

Since the creation of the world, the religious beliefs and morals of a particular religion significantly influenced the shaping of social behavior (Mokhlis, 2020). Distinctions in spiritual relations have a propensity to impact the way an individual spends his/ her life (Moschis, Mathur, and Sthienrapapayut, 2020), make decisions about the consumption (Gilal, Zhang, and Gilal, 2018a; Hashim, Musa, Nazri, and Ab Rahman, 2020), and purchase products they associate with themselves (Khan, Ghani, and Aziz, 2019). Studies document that people react to marketing activities according to the religious beliefs that influence their thinking patterns, perception, and behavior (Arli, de Araujo Gil, and van Esch, 2020; Gilal et al., 2020a). Everyone agrees that religious thoughts in several venerated forms have existed since the creation of human beings and that for centuries they have been part of humankind, irrespective of the religion in which an individual believes. However, religion and related matters have been widely studied, while division grounded in religiosity is part of several ongoing investigations (Stavrianea and Kamenidou, 2016). Currently, scholars show interest toward religion-based studies and have invited their attention by investigating the impacts of devotion to a religious way of life on purchase intentions for luxury brands (Salam, Muhamada, and Leong, 2019; Ustaahmetoğlu, 2020) and products made in other countries (Ahmed, Anang, Othman, and Sambasivan, 2013).

There are several ways to distinguish customers. Muslim customers are unique due to the robust impact of religion on their daily practices, beliefs, and deeds (Khan et al., 2020). A study on Muslim customers frequently refers to the obvious influence of religiosity on their preferences and purchase behaviors in different contexts (Uysal and Okumus, 2019). Scholars agree and effectively prove that a customer's behavior is directed by one's beliefs and morals (Minton, Johnson, and Liu, 2019). Many studies concentrate on the effects of religious beliefs, morals, and value on halal products (Awan, Siddiquei, and Haider, 2015; Elseidi, 2018), but few investigations link religiosity with purchase intention for luxury products (Dekhil, Boulebech and Bouslama, 2017; Aksoy and Abdulfatai, 2019). Therefore, one of the insights of the current study includes the lack of research in this area and the fact that - to our knowledge - no one has investigated the influence of intrinsic and extrinsic religiosity on purchase intentions for luxury brands in the luxury branding context of Pakistan. Therefore, we aim to fill this void by examining the influence of intrinsic and extrinsic religiosity on purchase intentions for luxury brands under the theoretical paradigm of self-determination theory (SDT). The SDT defines intrinsic and extrinsic motivation to suggest that human behavior is shaped by the fulfillment of either intrinsic or extrinsic motivation (Gilal 
et al., 2019a). Based on the theoretical perspective of SDT, we link customer religiosity to purchase intentions for luxury brands.

Besides investigating the relationship between a customer's religiosity and their purchase intention of a luxury brand, we also aim to examine the moderating effect of customer brand loyalty in the aforementioned relationship. Härtel and Russell-Bennett (2010) define loyalty as "the psychological preference for buying a brand that consists of positive feelings about and affective attachment to continually purchasing a brand" (2010, p. 2). Empirical research suggests several explanations related to customer brand loyalty. As such, studies refer to customer brand loyalty as a positive emotional experience (Xixiang, Gilal, and Gilal, 2016), a physical attribute-based satisfaction, and the perceived value of an experience that includes products or services (Gilal, Zhang, and Gilal, 2018a). Likewise, scholars view customer brand loyalty as a behavior where customers choose one brand of a product over its competing substitute (Gilal, Zhang, and Gilal, 2018b). Previously, scholars studied customer brand loyalty either as an independent variable (Magatef and Tomalieh, 2015) ora mediated variable (Tripathi, 2017). Loyalty was not tested as a moderating variable in religiosity research; therefore, we fill this void by studying customer brand loyalty as a moderating variable to examine whether the effect of intrinsic and extrinsic religiosity on luxury purchase intention is enhanced or undermined.

In summary, this study contributes to marketing literature in several important ways. First, we aid in marketing research by studying whether customers' intrinsic and extrinsic religiosity are capable of producing purchase intentions for luxury brands in customers. Second, we contribute to the exploration of whether customers' intrinsic or extrinsic religiosity is more promising in terms of increasing customer purchase intention for luxury brands. Third, we contribute to examinations on whether customer brand loyalty can moderate the impacts of customer religiosity (e.g. intrinsic and extrinsic) on purchase intention for luxury brands.

\section{Literature Review and Hypotheses Development}

\section{Religiosity and Customer Behavior}

There are several definitions related to the term 'religiosity.' In this study, we employ the definition of McDaniel and Burnett (1990). The authors state that "religiosity is a firm faith in God that is followed by a determinant to accept the disciplines that God has conveyed" (p. 101). It measures how much a person is committed and attached to certain values and religious credence, regardless of their environment (Beit-Hallahmi 
and Argyle, 1997). Religiosity is not just a multifaceted idea (Abou-Youssef et al., 2015); it is a multidimensional concept that connects many elements of religion that influence the lives of people. Religiosity contains beliefs, values, attitudes, knowledge, experiences, and practices that influence their lives (Abou-Youssef et al., 2015). Mittelstaedt (2002) develops a theoretical structure to demonstrate that religion has a positive impact on markets and the competitive system through sociopolitical and organizational factors that influence the extent to which Muslim customers are connected to God and to whom He grants His resources in power. In various religious societies, people have a strong belief that everything they have is bestowed by God.

Specifically, Eastern Asians are eager for luxury consumptions and switch luxury brand products abruptly (Gilal et al., 2018c). Nevertheless, scholarship focuses on individual religiosity toward behaviors like politics (Just, Sandovici, and Listhaug, 2014), marriage (Paprzycka, Polec, and Mianowska, 2020), and ethical codes (Aril and Tjiptono, 2014; Vitell, Singh, and Paolillo, 2007), while religious inspiration in customer behavior remains poorly investigated in the context of luxury goods (Cleveland and Chang, 2009). If luxury goods are often considered as a state of consumption (Arli, de Araujo Gil, and van Esch, 2020) and represent the affection of people for worldly possessions, it contradicts religion. Religiousness offers many customs in terms of worldly possession and is a point of advantage for many religious leaders who must live in a culture of consumption that enhances the spirit of faith (Aksoy and Abdulfatai, 2019). This view contradicts the religiosity of consuming luxury products. To recognize the affiliation regarding intrinsic and extrinsic religiosity concerning luxury brands and religiosity, we proposed the hypothesis of the essential values of an individual (Allport and Ross, 1967), which triggers stimuli to their attitude toward luxury brands as a purpose of social self-awareness and a mechanism of self-respect.

\section{Intrinsic Religiosity and Purchase Intention for a Luxury Brand}

Academic research on intrinsic and extrinsic inspiration in the customer marketing domain shows inconsistent results. As such, some authors reveal the negative impact of intrinsic motivation on customer behavior outcomes. For instance, Truong, McColl, and Kitchen (2010) study the structural influence of intrinsic motivation on luxury brand purchase intention and show that customers tend to favor luxury brands by sacrificing their intrinsic values. This standpoint is supported by Razmus, Jaroszyńska, and Palęga (2017), who reveal the negative effect of intrinsic motivation on customer brand engagement in self-concept. Likewise, Gilal et al. (2019b) report the trivial impact of customer intrinsic motivation on green customer behavior. Other author teams reported the positive relationship between intrinsic motivation and brand-related outcomes, such as a brand 
passion for apparel (Gilal et al., 2020b), airline brand adoption (Gilal et al., 2019c), customer brand loyalty (Lin, Tsai, and Chiu, 2009), and satisfaction (White, 2015).

Similarly, the literature on customer religiosity suggests that intrinsic religiosity plays a crucial role in life. As such, Nurhayati and Hendar (2019) show that personal intrinsic religiosity positively influences customer purchase intention for halal products. Abou-Youssef et al. (2015) reveal a significant positive effect of religiosity on customer attitudes toward Islamic banking in Egypt. Arli, de Araujo Gil, and van Esch (2020) document that young customers with high intrinsic religiosity possess an affective attitude toward luxury goods. A study conducted in Saudi Arabia by Abalkhail (2020) finds a positive effect of religiosity on luxury product consumption. A study conducted in South Korea reveals that the more religious customers are more inclined toward sustainable products (Minton, Kahle, and Kim, 2015). An empirical study in the Moroccan context by Nwankwo, Hamelin, and Khaled (2014) suggests that purchase intentions toward luxury goods are not influenced by religion, and the influence of religion appears to diminish as customer affordability of luxury goods increases. On the contrary, a recent study by Geiger-Oneto and Minton (2019) shows that religiosity influences negative moral emotions, which then negatively influences luxury consumption. These inconsistent results raise a doubt of whether intrinsic religiosity is capable of producing purchase intentions toward luxury goods in customers in the emerging market. Therefore, we formulated the following hypothesis to finally confirm the link:

$\mathbf{H}_{1}$ : Intrinsic religiosity is positively/negatively related to customers' purchase intentions for luxury brands.

\section{Extrinsic Religiosity and Purchase Intention for a Luxury Brand}

Researchers identify that customers who use luxury brands to differentiate themselves from the masses and place their values in society. They are more aware of their identity and positive image in social life (Nelissen and Meijers, 2011). Likewise, scholarship reveals that external factors positively influence the choice of customers for luxury brands (Truong, McColl, and Kitchen, 2010; Gilal et al., 2020b). Therefore, customers are inclined to value the brand and remain loyal to it and motivate themselves to be perceived by society as an important person. In contrast, while an enthusiastic person uses their religion extrinsically, others may be intrinsically motivated by their religion (Allport, 1950). Extrinsic religiosity tends to give greater importance to products of expressive value and social adaptation (Pace, 2014). Extrinsically religious people do not respect religious values and focus on individual preferences (Dekhil, Boulebech, and Bouslama, 2017;Agarwala, Mishra, and Singh, 2019). Extrinsicreligiosity motivates and encourages 
them to buy luxury brand products to show off and attract the appreciation of others (Casidy, Phau, and Lwin, 2016). Such people tend to enhance their social identity by adopting a particular style and expecting favorable comments and images, as they desire to connect with others (Burris and Jackson, 2000).

Luxury brands play a vital role for an extrinsically religious person. Such people rely on products to get satisfaction and show their identity based on luxury products (Arli and Tjiptono, 2014). Materialism is central to many customers'lives (for example, Belk, 1985; Burroughs and Rindfleisch, 2002; Vitell, Singh, and Paolillo, 2007; Ozgen and Esiyok, 2020). Moreover, materialism can be the main motivating factor in a person's life, exceeding the roles of religion, friendship groups, and other influences (Richins and Dawson, 1992; Jiang et al., 2015). Hence, if the luxury brand can influence the inherent religiosity in purchasing behavior, it can be used publicly and privately (Duan, 2020). However, researchers observed that most customers buy luxury brands because of their use to show off their social status (Wilcox, Kim, and Sen, 2009). Aksoy and Abdulfatai (2019) suggest a contrasting relationship between religiosity and luxury brands. They conclude that the purchase intention of Nigerian customers is guided by religious beliefs and morals. Moreover, a study from Burkina Faso notes the positive influence of intrinsic and extrinsic religiosity toward customer behavior. Hence, we hypothesize a link between extrinsic religiosity and purchase intentions for luxury brands:

$\mathbf{H}_{2}$ : Extrinsic religiosity is positively related to customers' purchase intentions for luxury brands.

\section{The Moderating Effect of Customer Brand Loyalty}

Härtel and Russell-Bennett (2010) define loyalty as "the psychological preference for buying a brand that consists of positive feelings about and affective attachment to continually purchasing a brand” (2010, p. 2). Empirical research by Dekhil, Jridi, and Farhat (2017), Kim et al. (2009), and Kim et al. (2014) identifies loyalty as an important moderating variable to link marketing environment to customer behavior outcomes. As such, Dekhil, Jridi, and Farhat (2017) examine the moderation of brand loyalty into the relationship between religiosity and decision to participate in a boycott and suggest that brand loyalty undermines the influence of religiosity on boycotting. Kim et al. (2014) reveal that a customer with high loyalty shows a stronger association between preview and repurchase intention through satisfaction than a customer with low loyalty. In line with these results, we believe that the more customers are loyal to the brand, the more they are likely to buy luxury brands. Hence, this leads us to think that loyalty can mode- 
rate the impact of intrinsic religiosity and extrinsic religiosity on purchase intention for luxury brands. Accordingly, we posit the following relationships:

$\mathbf{H}_{3}$ : The effect of intrinsic religiosity on purchase intention for luxury brands is stronger when customer brand loyalty is high than when brand loyalty is low.

$\mathbf{H}_{4}$ : The impact of extrinsic religiosity on purchase intention for luxury brands is stronger when customer brand loyalty is low than when brand loyalty is high.

Figure 1. Proposed conceptual model

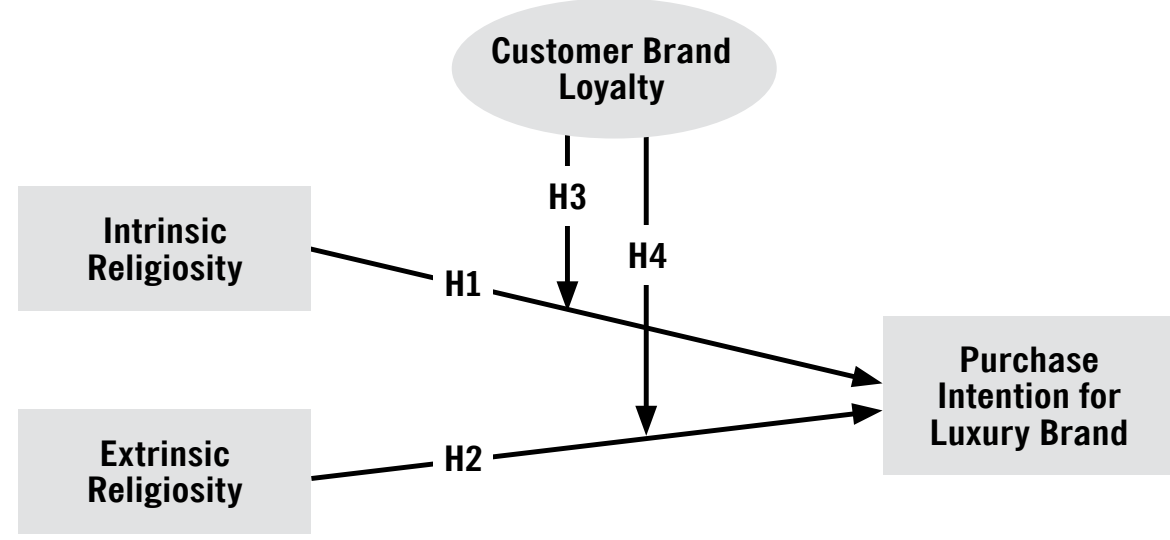

Source: own elaboration.

\section{Research Methodology}

\section{Procedure}

Based on the convenience sampling method, we recruited participants in two ways. First, undergraduate students from well-reputed business schools in Pakistan were approached in various campus locations, including the knowledge center (central library), cafeteria, photocopy shop, student lawn, and halls of classrooms. Second, young shoppers were contacted in the shopping malls in the metropolitan cities of Pakistan, including Sukkur, Karachi, and Hyderabad. The participants received a list of brands from three different product categories including clothing (e.g., Gul Ahmed, Diners, Oxford, Sana Safinaz, Outfitters, and J dot), footwear (e.g., Nike, Epcot, Borjan, Hush Puppies, and Gucci), and cell phones (e.g., Apple, Samsung, OnePlus, Nokia, and OPPO) with a request to ponder on the brands for five minutes. Next, we requested 
that participants select their preferred brands from the list, identifying those that they are attached to and willing to buy in the future. Participants who selected brands were then allowed to continue the survey, which mapped onto independent (e.g., intrinsic and extrinsic religiosity), dependent (e.g., luxury brand purchase intention), moderating (e.g., loyalty), and demographic (e.g., age, gender, education, etc.) variables.

\section{Participants}

After excluding invalid surveys that contained large numbers of missing values, 169 fully completed surveys were used for the data analysis. Among them, 59.2\% (100) were male, and $40.8 \%$ (69) were female participants, 90.5\% (153) of them aged 18-30 years at the time of the study, while 74.6\% (126) of participants were Muslims and 25.4\% (43) non-Muslims. Table 1 further indicates that 76.9\% (130) of participants had an undergraduate degree,while the remaining $23.1 \%$ (39) had a master's and doctoral degree: bachelor $=20.1 \%$ (34), MS/Ph.D. $=3 \%$ (5). Moreover, $83.40 \%$ (141) were students, and $75.7 \%$ (128) had a monthly income of PKR 10,000-20,000.

Table 1. Demographic statistics of respondents $(N=169)$

\begin{tabular}{|l|l|r|r|}
\hline \multicolumn{1}{|c|}{ Variable } & Characteristics & Frequency & Percent \\
\hline \multirow{2}{*}{ Gender } & Male & 100 & $59.2 \%$ \\
\hline \multirow{2}{*}{ Age } & Female & 69 & $40.8 \%$ \\
\hline \multirow{3}{*}{ Education } & $18-30$ & 153 & $90.5 \%$ \\
\hline \multirow{3}{*}{ Religion } & $31-40$ & 16 & $9.5 \%$ \\
\hline \multirow{2}{*}{ Profession/0ccupation } & Bachelor & 130 & $76.9 \%$ \\
\hline & Master & 34 & $20.1 \%$ \\
\hline & MS/PhD & 5 & $3.0 \%$ \\
\hline & Muslim & 126 & $74.6 \%$ \\
\hline & Non-Muslim & 43 & $25.4 \%$ \\
\hline & Employee & 141 & $83.4 \%$ \\
\hline Monthly Income & $10000-20000$ PKR & 28 & $16.6 \%$ \\
\hline & $20001-40000$ PKR & 128 & $75.7 \%$ \\
\hline & $40001-50000$ PKR & 15 & $8.9 \%$ \\
\hline & Above 50000 PKR & 3 & $1.8 \%$ \\
\hline & & 23 & $13.6 \%$ \\
\hline
\end{tabular}

Source: own elaboration. 


\section{Measurement}

Consistent with prior cross-sectional studies, we drew items for measuring all constructs from adapted research and implemented minor revisions to the original scale based on the feedback from respondents of a pilot study. The survey was designed in the English language as it is an official language in Pakistan. Intrinsic and extrinsic religiosity was assessed with six- and five-item scales, respectively, adapted from Arli, Cherrier, and Tjiptono (2016). The five items related to customer brand loyalty were drawn from recent research by Dekhil, Jridi, and Farhat (2017). Customer purchase intention for a luxury brand was assessed on four items from Arli, Cherrier, and Tjiptono (2016). All items were measured using a five-point scale, while Cronbach's alpha for intrinsic religiosity ( $\alpha=0.939)$, extrinsic religiosity $(\alpha=0.853)$, purchase intention for luxury brand ( $\alpha=0.766)$, and brand loyalty ( $\alpha=0.893$ ) exceeded predefined threshold levels (i.e., 0.70).

\section{Results}

\section{EFA}

Before testing the structural relationship between variables, we first conducted an EFA with the Varimax rotation method to examine whether the items can effectively reflect their corresponding factor. Our results presented in Table 2 suggest a four-factor solution, explaining $80.862 \%$ of the total variance. Based on extant literature, the first factor was labeled as customer brand loyalty (CL), which represented $25.389 \%$ of the variance; however, one item of CL was removed due to a low factor score of 0.60 (Reio and Shuck, 2015). The second factor was labeled as intrinsic religiosity (IR), which explained $22.329 \%$ of the variance, and three items were dropped due to the unacceptable range of factor scores (Reio and Shuck, 2015). The third factor was labeled extrinsic religiosity (ER), which explained 19.651\% of the variance, and two items of ER were removed based on the unacceptable range of factor scores(Reio and Shuck, 2015). Finally, the fourth factor was labeled as luxury brand purchase intention, which explained $13.493 \%$ of the variance; two items of luxury brand purchase intention were removed due to the unacceptable range of factor scores (Reio and Shuck, 2015). Finally, Kaiser-Meyer-Olkin was 0.748 , which was above the acceptable range of 0.60 , while the Bartlett sphericity test $\left[\chi^{2}(66)=12483.953, p<0.001\right]$ was statistically significant, indicating the suitability of the data for further analysis (Reio and Shuck, 2015). 
Table 2. Results of exploratory factor analysis

\begin{tabular}{|c|c|c|c|c|c|}
\hline Factors & $\begin{array}{l}\text { Factor } \\
\text { Score }\end{array}$ & $\begin{array}{l}\text { Variance } \\
\text { Explained }\end{array}$ & Eigenvalue & $\begin{array}{l}\text { Cumulative } \\
\% \text { of Variance }\end{array}$ & $\begin{array}{l}\text { Cronbach's } \\
\text { Alpha }\end{array}$ \\
\hline \multicolumn{2}{|c|}{ Factor 1: Consumer brand loyalty (CBL) } & $25.389 \%$ & 3.05 & $25.389 \%$ & .893 \\
\hline CBL2 & .899 & & & & \\
\hline CBL3 & .885 & & & & \\
\hline CBL5 & .851 & & & & \\
\hline CBL1 & .831 & & & & \\
\hline \multicolumn{2}{|c|}{ Factor 2: Intrinsic religiosity (IR) } & $22.329 \%$ & 2.68 & $47.718 \%$ & .939 \\
\hline IR1 & .959 & & & & \\
\hline IIR3 & .942 & & & & \\
\hline IR2 & .922 & & & & \\
\hline \multicolumn{2}{|c|}{ Factor 3:Extrinsic religiosity (ER) } & $19.651 \%$ & 2.36 & $67.369 \%$ & .853 \\
\hline ER1 & .893 & & & & \\
\hline ER2 & .872 & & & & \\
\hline ER3 & .838 & & & & \\
\hline \multicolumn{2}{|c|}{$\begin{array}{l}\text { Factor 4: Purchase intentions for luxury } \\
\text { brand (PILB) }\end{array}$} & $13.493 \%$ & 1.62 & $80.862 \%$ & .766 \\
\hline PILB2 & .875 & & & & \\
\hline PILB1 & .868 & & & & \\
\hline
\end{tabular}

Note: $\mathrm{CBL}=$ customer brand loyalty; $\mathrm{IR}=$ intrinsic religiosity; $\mathrm{ER}=$ extrinsic religiosity; PILB = purchase intention for a luxury brand.

Source: own elaboration.

\section{Convergent Validity}

Next, we performed CFA to examine the convergent validity of the measurement model. Our data indicated that the composite reliability (CR) and average variance extracted (AVE) for intrinsic religiosity $(\mathrm{CR}=0.958$; $\mathrm{AVE}=0.884)$, extrinsic religiosity $(\mathrm{CR}=0.911$; $\mathrm{AVE}=0.773)$, purchase intention for the luxury brand $(\mathrm{CR}=0.895$; $\mathrm{AVE}=0.810$ ), and customer brand loyalty ( $\mathrm{CR}=0.925$; AVE $=0.756$ ) values fall within the acceptable 
range of 0.70 and 0.50 , respectively. Thus, they support a good convergent validity (Hu and Bentler, 1999), as presented in Table 3.

Table 3. Convergent validity

\begin{tabular}{|c|c|c|c|c|}
\hline Variable & Item & $\begin{array}{l}\text { Standardized } \\
\text { factor loading }\end{array}$ & $\begin{array}{l}\text { Composite } \\
\text { reliability }\end{array}$ & $\begin{array}{c}\text { Average variance } \\
\text { extracted }\end{array}$ \\
\hline \multirow{4}{*}{ Customer brand loyalty } & CBL2 & .867 & \multirow{4}{*}{.925} & \multirow{4}{*}{.756} \\
\hline & CBL3 & .850 & & \\
\hline & CBL5 & .821 & & \\
\hline & CBL1 & .758 & & \\
\hline \multirow{3}{*}{ Intrinsic religiosity } & IR1 & .972 & \multirow{3}{*}{.958} & \multirow{3}{*}{.884} \\
\hline & IR3 & .929 & & \\
\hline & IR2 & .845 & & \\
\hline \multirow{3}{*}{ Extrinsic religiosity } & ER1 & .913 & \multirow{3}{*}{.911} & \multirow{3}{*}{.773} \\
\hline & ER2 & .775 & & \\
\hline & ER3 & .757 & & \\
\hline \multirow{2}{*}{$\begin{array}{l}\text { Purchase intention } \\
\text { for a luxury brand }\end{array}$} & PILB2 & .779 & \multirow{2}{*}{.895} & \multirow{2}{*}{.810} \\
\hline & PILB1 & .796 & & \\
\hline
\end{tabular}

Note: $\mathrm{CBL}=$ customer brand loyalty; $\mathrm{IR}=$ intrinsic religiosity; $\mathrm{ER}=$ extrinsic religiosity; $\mathrm{PILB}=$ purchase intention for a luxury brand.

Source: own elaboration.

\section{Discriminant Validity}

Next, we ran CFAto examine discriminant validity. Based on the procedure suggested in extant literature (Chen, Zhang, and Gilal, 2019; Gong et al., 2019; Zhang, Gong, Xu, and Gilal, 2019), we compared a four-factor model with a three-factor model, two-factor model, and a one-factor model. Our findings presented in Table 4 reveal that the three-factor model- the model comprised of intrinsic religiosity, extrinsic religiosity, purchase intention for a luxury brand, and customer brand loyalty-fitted the data more closely than the other three models, which suggested that the four variables are statistically different. 
Table 4. Discriminant validity: model comparison

\begin{tabular}{|c|c|c|c|c|c|c|c|c|}
\hline Model & Factor Loaded & $X_{2} / d f$ & CFI & NFI & TLI & GFI & SRMR & RMSEA \\
\hline 1 & 4-Factors: CBL, IR, ER, PILB & 1.35 & .97 & .95 & .98 & .94 & .057 & .046 \\
\hline 2 & 3-Factors: CBL/IR, ER, PILB & 10.69 & .59 & .58 & .48 & .71 & .370 & .240 \\
\hline 3 & 2-Factors: CBL/IR, ER/PILB & 11.76 & .53 & .51 & .42 & .67 & .381 & .253 \\
\hline 4 & 1-Factor: all variables combine & 16.21 & .33 & .32 & .18 & .57 & .451 & .301 \\
\hline
\end{tabular}

Note: $\mathrm{CBL}=$ customer brand loyalty; $\mathrm{IR}=$ intrinsic religiosity; $\mathrm{ER}=$ extrinsic religiosity; PILB $=$ purchase intention for a luxury brand.

Source: own elaboration.

\section{Correlation Analysis}

Our results presented in Table 5 reveal that intrinsic religiosity insignificantly correlated with customer purchase intention for a luxury brand ( $r=0.080 ; \mathrm{p}=\mathrm{ns}$.), whereas extrinsic religiosity strongly correlated with purchase intention for a luxury brand $\left(r=0.329^{* *}\right)$. Similarly, customer brand loyalty is correlated positively with customer purchase intention for a luxury brand $\left(\mathrm{r}=0.219^{* *}\right)$. These conclusions generally support the potential effects of extrinsic religiosity and customer brand loyalty on purchase intention for a luxury brand.

Table 5. Means, standard deviations, and correlations between measured variables

\begin{tabular}{|l|l|l|l|l|l|l|}
\hline Variables & M & SD & IR & ER & CBL & PILB \\
\hline IR & 3.485 & 1.402 & 1 & $-110 n s$ & $.047 n s$ & $.080 n s$ \\
\hline ER & 3.444 & 1.147 & & 1 & $-.049 n s$ & $.329 * *$ \\
\hline CBL & 3.868 & 0.691 & & & 1 & $.219 * *$ \\
\hline PILB & 3.861 & 1.018 & & & & 1 \\
\hline
\end{tabular}

Note: ${ }^{* *} \mathrm{p}<0.01 ; \mathrm{ns}=$ nonsignificant; $\mathrm{CBL}=$ customer brand loyalty; $\mathrm{IR}=$ intrinsic religiosity; $\mathrm{ER}=$ extrinsic religiosity; PILB $=$ purchase intention for a luxury brand.

Source: own elaboration.

\section{SEM}

Next, SEM was conducted to investigate the structural effect of intrinsic and extrinsic religiosity purchase intention for a luxury brand.As evidenced by the results, the hypothesized SEM excellently fitted the data: CMIN/DF (26.990/17) = 1.588; CFI = 0.988; 
$\mathrm{TLI}=0.980 ; \mathrm{RFI}=0.947 ; \mathrm{NFI}=0.968 ; \mathrm{RMR}=0.075 ; \mathrm{RMSEA}=0.059 ; \mathrm{PCLOSE}=0.326 ;$ AIC $=64.990$. Next, we examine the structural paths to inspect the relationships between hypothesized variables. $\mathrm{H}_{1}$ is not supported, as it states that intrinsic religiosity is positively associated with customers' purchase intention for a luxury brand $\left(\beta=0.161^{\mathrm{ns}} ; \mathrm{t}=1.855 ; \mathrm{p}=\mathrm{ns}\right) . \mathrm{H}_{2}$ posits that extrinsic religiosity is positively associated with customers' purchase intention for a luxury brand. This hypothesis is supported $\left(b=0.368^{* * *} ; t=3.810 ; p<0.001\right)$. Overall, the results of the SEM show that purchase intention for a luxury brand is significantly influenced by extrinsic religiosity and that extrinsic religiosity seemed to be an important predictor of purchase intention for a luxury brand. In the next section, we examined in detail the moderating effects of customer brand loyalty.

\section{Moderating Effects of Customer Brand Loyalty}

$\mathrm{H}_{3}$ and $\mathrm{H}_{4}$ are related to the moderating effect of customer brand loyalty that was tested based on the procedure recommended by Hayes (2015). $\mathrm{H}_{3}$ states that customer brand loyalty would moderate the link between intrinsic religiosity and customer purchase intention for a luxury brand. This relationship is supported $\left(\beta=0.272^{* * *} ; t=3.959\right.$; $\mathrm{p}<0.001$ ). Our findings presented in Table 6 further suggest that customer purchase intention for luxury brands is better captured by intrinsic religiosity when customer brand loyalty is high $\left(\beta=0.245^{* * *} ; \mathrm{t}=3.40 ; \mathrm{p}<0.001 ; \mathrm{CI}=0.103\right.$ to 0.387$)$ but not when customer brand loyalty is low ( $\beta=0.131^{\mathrm{ns}} ; \mathrm{t}=-1.87$; $\mathrm{p}=\mathrm{ns}$; $\mathrm{CI}=-0.269$ to 0.007 ). Similarly, $\mathrm{H}_{4}$ posits that customer brand loyalty moderates the link between extrinsic religiosity and purchase intention for a luxury brand. Our data supports this link $\left(\beta=-0.186^{*} ; t=-2.281 ; p<0.05\right)$. Our findings further indicate that the effect of extrinsic religiosity on purchase intention for luxury brands is reinforced by extrinsic religiosity when customer brand loyalty is low $\left(\beta=0.449^{* * *} ; \mathrm{t}=5.014 ; \mathrm{p}<0.001\right.$ : $\mathrm{CI}=0.272$ to 0.626 ) than for high customer brand loyalty $\left(\beta=0.192^{*} ; \mathrm{t}=2.430 ; \mathrm{p}<0.05\right.$ : $\mathrm{CI}=0.036$ to 0.348 ). Overall, these findings undoubtedly reflect that people chasing extrinsic life goals are less happy and more depressed than those chasing intrinsic life goals. 
Table 6. The moderating effect of customer brand loyalty

\begin{tabular}{|c|c|c|c|c|c|c|}
\hline (a) & The moderating & fect of CB & on PILB a & depende & variabl & \\
\hline Predictor & Estimate & t-value & $p$-value & $\mathbf{F}$ & $\mathbf{R}^{2}$ ( & ange) \\
\hline $\mathrm{CBL}$ & -.547 & -2.250 & 0.026 & & & \\
\hline IR & -.994 & -3.695 & 0.000 & 8.586 & & 82) \\
\hline $\mathrm{IR} \times \mathrm{CBL}$ & .272 & 3.959 & 0.000 & & & \\
\hline$C B L \pm 1 S D$ & Conditional Estimate & SE & t-value & p-value & LLCI & ULCI \\
\hline Low & .131 & .070 & -1.87 & 0.062 & -.269 & .007 \\
\hline High & .245 & .072 & 3.40 & 0.001 & .103 & .387 \\
\hline (b) & The moderating & fect of CB & on PILB a & depende & variabl & \\
\hline Predictor & Estimate & t-value & p-value & $\mathbf{F}$ & $\mathbf{R}^{2}$ ( & ange) \\
\hline $\mathrm{CBL}$ & .970 & 3.324 & 0.001 & & & \\
\hline ER & 1.041 & 3.156 & 0.002 & 12.86 & & 26) \\
\hline $\mathrm{ER} \times \mathrm{CBL}$ & -.186 & -2.281 & 0.024 & & & \\
\hline$C B L \pm 1 S D$ & Conditional Estimate & SE & t-value & p-value & LLCI & ULCI \\
\hline Low & .449 & .090 & 5.014 & 0.000 & .272 & .626 \\
\hline High & .192 & .079 & 2.430 & 0.016 & .036 & .348 \\
\hline
\end{tabular}

Note: $\mathrm{CBL}=$ customer brand loyalty; $\mathrm{IR}=$ intrinsic religiosity; $\mathrm{ER}=$ extrinsic religiosity; PILB = purchase intention for a luxury brand.

Source: own elaboration.

\section{Discussion}

This study is the first of its kind to link customer religiosity to purchase intention for luxury brands under the theoretical paradigm of SDT. The present study aids in extant marketing literature in numerous ways. Firstly, the study contributes to investigations into whether intrinsic religiosity and extrinsic religiosity are capable of increasing customers' purchase intentions for luxury brands and whether intrinsic religiosity or extrinsic religiosity is more promising in these relationships. Secondly, we explored whether customer brand loyalty contributed to enhance or undermine the influence 
of customer intrinsic religiosity and extrinsic religiosity on luxury brand purchase intention.

In line with our hypothesis, when intrinsic religiosity and extrinsic religiosity were assessed, extrinsic religiosity had the strongest effect on customer purchase intention for luxury brands. This is an interesting finding that indicates extrinsic religiosity plays an important role in capturing customer purchase intentions for luxury brands. These results match those observed in earlier empirical studies, which reported that extrinsic motivation positively increases customer preference for luxury brands (Truong, McColl, and Kitchen, 2010), brand engagement in self-concept (Razmus, Jaroszyńska, and Palęga, 2017), and brand passion for clothing brands (Gilal et al., 2020b).

Similarly, our data further suggest that intrinsic religiosity is insignificantly related to purchasing intention for a luxury brand. This finding indicates that intrinsic religiosity does not play an important role in improving customer purchase intention for a luxury brand. This can be ascribed to the fact that intrinsically religious individuals tend to focus less on luxurious goods (Gilal et al., 2020a), and they prefer not to compromise their beliefs and core values by consuming the symbolic goods. Although these results are consistent with those of Gilal et al. (2020b), Truong, McColl, and Kitchen (2010), and Razmus, Jaroszyńska, and Palęga (2017), they differ from some published papers which document the positive effect of intrinsic motivation on the passion for a clothing brand (Gilal et al., 2020b), airline brand adoption (Gilal et al., 2019c), customer brand loyalty (Lin, Tsai, and Chiu, 2009), satisfaction (White, 2015), and purchase intention (Agarwala, Mishra, and Singh, 2019).

Finally, the result of moderation analysis (customer brand loyalty) shows that the effect of extrinsic religiosity on purchase intention for a luxury brand is reinforced by extrinsic religiosity when customer brand loyalty is low than when it is high. Likewise, customer purchase intention for the luxury brand is better captured by intrinsic religiosity when customer brand loyalty is high, but not when customer brand loyalty is low. This finding suggests that individuals described as intrinsically holding religious views tend to prefer luxury goods when loyalty toward that brand is high, but not when that loyalty is low. This can be true since people holding intrinsic religious views are true believers. This finding supports previous research by Dekhil, Jridi, and Farhat (2017), which revealed that brand loyalty significantly diminishes the effect of religiosity on the intention to participate in boycotts. 


\section{Theoretical and Practical Implications}

Based on the comprehensive model of customer religiosity, this study makes several contributions to theory and practice. Although considerable attention has been paid to investigating the influence of religiosity on happiness (French and Joseph, 1999), anxiety (Baroun, 2006), voter turnout (Gerber, Gruber, and Hungerman, 2016), wellbeing (Abdel-Khalek, 2019), and corporate social responsibility (Chantziaras et al., 2020), the subject of religiosity and customer behavior regarding luxury brand purchase intention has yet to be fully addressed in academic research in emerging markets, such as Pakistan. Therefore, this study advances marketing literature by studying intrinsic religiosity and extrinsic religiosity as antecedents of luxury brand purchase intention in the luxury branding context. Particularly, we have made the following theoretical contributions. Firstly, this paper provides a fresh perspective on the prominence of customer religiosity by applying the theoretical paradigm of SDT. The SDT categorizes intrinsic and extrinsic motivation and suggests that human behavior is shaped by the fulfillment of either intrinsic or extrinsic motivation (Gilal, Zhang, Paul, and Gilal, 2019a). Based on the SDT, our paper elucidates that extrinsic religiosity significantly increases the luxury brand's purchase intention. As a result, this paper contributes to extending the theoretical paradigm of SDT by indicating that a luxury brand purchase intention can be improved in the luxury branding context through extrinsic religiosity.

Our study produces important implications for luxury manufacturing tycoons in general and marketing managers of luxury clothing, cell phone, and footwear brands in particular. From the managerial perspective, the findings suggest that when intrinsic religiosity and extrinsic religiosity were assessed, extrinsic religiosity had the strongest effect on customers' purchase intentions for luxury brands, while luxury brand purchase intention is trivially influenced by intrinsic religiosity. This indicates that extrinsic religiosity is the most important predictor of a luxury brand purchase intention in the luxury branding context. Therefore, taking into account the findings of the current article, marketing managers of luxury brands who seek to build luxury brand purchase intention are encouraged to focus more on meeting/fulfilling customer extrinsic motivation. Specifically, brand managers and strategists who understand the link between extrinsic religiosity and luxury brand purchase intention will help firms to compete in a dynamic market and gain better business results.

Moreover, let us note that purchase intention for a luxury brand is reinforced by intrinsic religiosity when customer brand loyalty is high than when customer brand loyalty is low, whereas luxury brand purchase intention is strengthened more by extrinsic religiosity when customer brand loyalty is low than when it is high. These results regarding 
the moderating effect of customer brand loyalty can be used as a reference for brand managers for crafting marketing strategies. Strategists and luxury manufacturing tycoons in general and marketing managers of luxury clothing, cell phone, and footwear brands, in particular, may benefit from this article by redesigning market segmentation, targeting, and positioning strategies for building luxury brand purchase intention among customers.

\section{Limitations and Future Directions}

As with any set of studies, our research is not without limitations. As with all cross-sectional studies, the sample size in the current study is purposefully small. This limits the generalizability of findings across a wider population. Likewise, we recruited participants from the urban population of Pakistan, so the sample does not represent a whole and accurate picture of the demographic data in Pakistan. Both researchers and market practitioners must be careful of the implications they draw from the current study. Therefore, we encourage marketing scholars to revalidate our hypotheses on a larger sample size. If possible, they should compare and contrast the results of a sample drawn from developed and developing countries that are culturally and religiously unique. Secondly, our research uncovers the trivial link between intrinsic religiosity and luxury brand purchase intention. There is a chance that intrinsic religiosity may indirectly impact purchase intention for a luxury brand through mediating variables. For instance, a recent study by Arli, de Araujo Gil, and van Esch (2020, p. 2) reported that "religious youth customers love God, but they also love Gucci (i.e., luxury goods)." Therefore, future scholarship should consider mediating variables to find the missing links. Third, this research does not compare and contrast male and female customers (Gilal et al., 2019b; Gilal et al., 2020b), older and young customers (Gilal et al., 2020b), or religious and non-religious customers (Arli and Pekerti, 2017). We invite scholars to fill this gap by testing the moderating effect of these variables using either the newly introduced moderated moderated-mediation technique (Gilal et al., 2018d) or multigroup analysis (Byrne, 2004) so as to gain a more comprehensive set of results.

\section{References}

Abalkhail, T.S. (2020). The impact of religiosity on luxury brand consumption: the case of Saudi customers. Journal of Islamic Marketing, 1-12. https://doi.org/10.1108/JIMA-11-2016-0091.

Abdel-Khalek, A.M. (2019). Religiosity and subjective well-being in the Arab context: addendum and extrapolation. Mental Health, Religion \& Culture, 22(8), 860-869.

https://doi.org/10.1080/13674676.2019.1687135. 
Abou-Youssef, M.M.H., Kortam, W., Abou-Aish, E., and El-Bassiouny, N. (2015). Effects of religiosity on customer attitudes toward Islamic banking in Egypt. International Journal of Bank Marketing, 33(6), 786-807. https://doi.org/10.1108/IJBM-02-2015-0024.

Agarwala, R., Mishra, P., and Singh, R. (2019). Religiosity and customer behavior: A summarizing review. Journal of Management, Spirituality \& Religion, 16(1), 32-54. https://doi.org/10.1080/14766086.2018.1495098.

Ahmed, Z., Anang, R., Othman, N. and Sambasivan, M. (2013). To purchase or not to purchase US products: role of religiosity, animosity, and ethnocentrism among Malaysian customers. Journal of Services Marketing, 29(7), 551-563. https://doi.org/10.1108/JSM-01-2012-0023.

Aksoy, H. and Abdulfatai, O.Y. (2019). Exploring the impact of religiousness and culture on luxury fashion goods purchasing intention. Journal of Islamic Marketing, 10(3), 768-789. https://doi.org/10.1108/JIMA-01-2018-0022.

Allport, G.W. (1950). Prejudice: A problem in psychological and social causation. Journal of Social Issues, 6(S4), 4-23. https://doi.org/10.1111/j.1540-4560.1950.tb02175.x.

Allport, G.W. and Ross, J.M. (1967). Personal religious orientation and prejudice. Journal of Personality and Social Psychology, 5(4), 432-443. https://doi.org/10.1037/h0021212.

Arli, D., de Araujo Gil, L., and van Esch, P. (2020). The effect of religiosity on luxury goods: The case of Chilean youths. International Journal of Customer Studies.

1-10. https://doi.org/10.1111/ijcs.12559.

Arli, D., Cherrier, H., and Tjiptono, F. (2016). God blesses those who wear Prada. Marketing Intelligence \& Planning, 34(1), 61-79. https://doi.org/10.1108/MIP-12-2014-0232.

Arli, D. and Pekerti, A. (2017). Who is more ethical? Cross-cultural comparison of customer ethics between religious and non-religious customers. Journal of Customer Behaviour, 16(1), 82-98. https://doi.org/10.1002/cb.1607.

Arli, D. and Tjiptono, F. (2014). The end of religion? Examining the role of religiousness, materialism, and long-term orientation on customer ethics in Indonesia. Journal of Business Ethics, 123(3), 385-400. https://doi.org/10.1007/s10551-013-1846-4.

Awan, H.M., Siddiquei, A.N., and Haider, Z. (2015). Factors affecting Halal purchase intention-evidence from Pakistan's Halal food sector. Management Research Review, 38(6), 640-660. https://doi.org/10.1108/MRR-01-2014-0022.

Baroun, K.A. (2006). Relations among religiosity, health, happiness, and anxiety for Kuwaiti adolescents. Psychological Reports, 99(3), 717-722. https://doi.org/10.2466/PR0.99.3.717-722.

Beit-Hallahmi, B. and Argyle, M. (1997). The psychology of religious behavior, belief, and experience. Taylor \& Francis.

Belk, R.W. (1985). Materialism: Trait aspects of living in the material world. Journal of Customer Research, 12(3), 265-280. https://doi.org/10.1086/208515.

Burris, C.T., and Jackson, L.M. (2000). Social identity and the true believer: Responses to threatened self-stereotypes among the intrinsically religious. British Journal of Social Psychology, 39(2), 257-278. https://doi.org/10.1348/014466600164462.

Burroughs, J.E., and Rindfleisch, A. (2002). Materialism and well-being: A conflicting values perspective. Journal of Customer Research, 29(3), 348-370. https://doi.org/10.1086/344429.

Byrne, B.M. (2004). Testing for multigroup invariance using AMOS graphics: A road less traveled. Structural Equation Modeling, 11(2), 272-300. https://doi.org/10.1207/s15328007sem1102_8.

Casidy, R., Phau, I. and Lwin, M. (2016). Religiosity and digital piracy: An empirical examination. Services Marketing Quarterly, 37(1), 1-13. https://doi.org/10.1080/15332969.2015.1112172. 
Chantziaras, A., Dedoulis, E., Grougiou, V. and AndLeventis, S. (2020). The impact of religiosity and corruption on CSR reporting: The case of US banks. Journal of Business Research, 109, 362-374. https://doi.org/10.1016/j.jbusres.2019.12.025.

Chen, C.X., Zhang, J. and Gilal, F.G. (2019). Composition of motivation profiles at work using latent analysis: theory and evidence. Psychology Research and Behavior Management, 12, 811-824. https://doi.org/10.2147/PRBM.S210830.

Cleveland, M. and Chang, W. (2009). Migration and materialism: The roles of ethnic identity, religiosity, and generation. Journal of Business Research, 62(10), 963-971.

https://doi.org/10.1016/j.jbusres.2008.05.022.

Dekhil, F., Boulebech, H. and Bouslama, N. (2017). Effect of religiosity on luxury customer behavior: the case of the Tunisian Muslim. Journal of Islamic Marketing, 8(1), 74-94. https://doi.org/10.1108/JIMA-09-2012-0051.

Dekhil, F., Jridi, H., and Farhat, H. (2017). Effect of religiosity on the decision to participate in a boycott. Journal of Islamic Marketing, 8(2), 309-328. https://doi.org/10.1108/JIMA-01-20130008. https://doi.org/10.1108/JIMA-01-2013-0008.

Duan, J. (2020). Materialism and purchase-evoked happiness: A moderated mediation model of purchase type and purchase's impact on self. Journal of Global Scholars of Marketing Science, 30(2), 170-187. https://doi.org/10.1080/21639159.2019.1700150.

Elseidi, R.I. (2018). Determinants of halal purchasing intentions: evidence from the UK. Journal of Islamic Marketing, 9(1), 167-190. https://doi.org/10.1108/JIMA-02-2016-0013.

French, S. and Joseph, S. (1999). Religiosity and its association with happiness, purpose in life, and self-actualization. Mental Health, Religion \& Culture, 2(2), 117-120. https://doi.org/10.1080/13674679908406340.

Geiger-Oneto, S. and Minton, E.A. (2019). How religiosity influences the consumption of luxury goods: the exploration of the moral halo effect. European Journal of Marketing, 53(12), 2530-2555. https://doi.org/10.1108/EJM-01-2018-0016.

Gerber, A.S., Gruber, J., and Hungerman, D.M. (2016). Does church attendance cause people to vote? Using blue laws' repeal to estimate the effect of religiosity on voter turnout. British Journal of Political Science, 46(3), 481-500. https://doi.org/10.1017/S0007123414000416.

Gilal, N.G., Zhang, J., and Gilal, F.G. (2018a). Linking product design to customer behavior: the moderating role of the consumption experience. Psychology Research and Behavior Management, 11, 169-185. https://doi.org/10.2147/PRBM.S161384.

Gilal, N.G., Zhang, J., and Gilal, F.G. (2018b). The four-factor model of product design: scale development and validation. Journal of Product and Brand Management, 27(6), 684-700. https://doi.org/10.1108/JPBM-11-2017-1659.

Gilal, F.G., Zhang, J., Gilal, N.G., and Gilal, R.G. (2018c). Integrating self-determined needs into the relationship among product design, willingness-to-pay a premium, and word-of-mouth: a cross-cultural gender-specific study. Psychology Research and Behavior Management, 11, 227-241. https://doi.org/10.2147/PRBM.S161269.

Gilal, F.G., Zhang, J., Gilal, R.G., and Gilal, N.G. (2020a). Integrating intrinsic motivation into the relationship between product design and brand attachment: A cross-cultural investigation based on self-determination theory. European Journal of International Management, 14(1), 1-27. https://doi.org/10.1504/EJIM.2020.103800.

Gilal, F.G., Zhang, J., Gilal, R.G., and Gilal, N.G. (2020b). Linking motivational regulation to brand passion in a moderated model of customer gender and age: an organismic integration theory perspective. Review of Managerial Science, 14(1), 87-113. https://doi.org/10.1007/s11846-0180287-y. 
Gilal, F.G., Zhang, J., Paul, J., and Gilal, N.G. (2019a). The role of self-determination theory in marketing science: An integrative review and agenda for research. European Management Journal, 37(1), 29-44. https://doi.org/10.1016/j.emj.2018.10.004.

Gilal, F.G., Chandani, K., Gilal, R.G., Gilal, N.G., Gilal, W.G., and Channa, N.A. (2019b). Towards a new model for green customer behavior: A self-determination theory perspective. Sustainable Development, 1-12. https://doi.org/10.1002/sd.2021.

Gilal, N.G., Zhang, J., Gilal, F.G., and Gilal, R.G. (2019c). Towards an integrated model for brand adoption: Insights from an organismic integration theory. European Journal of International Management. https://doi.org/10.1504/EJIM.2019.10018446.

Gong, Z., Liu, M., Xin, D., Gilal, F.G., Yin, K. and Zhang, N. (2019). Coworker feedback-seeking and feedback environment in China: An expectation states theory approach. Social Behavior and Personality: An International Journal, 47(9), 1-10. https://doi.org/10.2224/sbp.8392.

Härtel, C.E. and Russell-Bennett, R. (2010). Heart versus mind: The functions of emotional and cognitive loyalty. Australasian Marketing Journal, 18(1), 1-7. https://doi.org/10.1016/j.ausmj.2009.10.003.

Hashim, A.J., Musa, R., Nazri, M.A., and Ab Rahman, N.A.F.W. (2020). Roles of Spiritual Intelligence and Spiritual Congruence in Purchasing Halal Skin Care Products Among Adult Urban Muslim Career Woman. Journal of Fatwa Management and Research, 59-77.

Hayes, A.F. (2015). An index and test of linear moderated mediation. Multivariate Behavioral Research, 50(1), 1-22. https://doi.org/10.1080/00273171.2014.962683.

Hu, L.T. and Bentler, P.M. (1999). Cutoff criteria for fit indexes in covariance structure analysis: Conventional criteria versus new alternatives. Structural Equation Modeling: A Multidisciplinary Journal, 6(1), 1-55. https://doi.org/10.1080/10705519909540118.

Jiang, J., Zhang, Y., Ke, Y., Hawk, S.T. and Qiu, H. (2015). Can’t buy me friendship? Peer rejection and adolescent materialism: Implicit self-esteem as a mediator. Journal of Experimental Social Psychology, 58, 48-55. https://doi.org/10.1016/j.jesp.2015.01.001.

Just, A., Sandovici, M.E. and Listhaug, O. (2014). Islam, religiosity, and immigrant political action in Western Europe. Social Science Research, 43, 127-144. https://doi.org/10.1016/j.ssresearch.2013.09.005.

Khan, M.A., Ghani, U. and Aziz, S. (2019). Impact of Islamic Religiosity on Customers' Attitudes towards Islamic and Conventional ways of Advertisements, Attitude towards Brands and Purchase Intentions. Business \& Economic Review, 11(1), 1-30. https://doi.org/10.22547/BER/11.2.1.

Khan, W., Akhtar, A., Ansari, S.A., and Dhamija, A. (2020). Enablers of halal food purchase among Muslim customers in an emerging economy: an interpretive structural modeling approach. British Food Journal, 1-16. https://doi.org/10.1108/BFJ-08-2018-0528.

Kim, D., Lee, S.Y., Bu, K., and Lee, S. (2009). Do VIP programs always work well? The moderating role of loyalty. Psychology and Marketing, 26(7), 590-609. https://doi.org/10.1002/mar.20290.

Kim, M.J., Lee, C.K., Chung, N., and Kim, W.G. (2014). Factors affecting online tourism group buying and the moderating role of loyalty. Journal of Travel Research, 53(3), 380-394. https://doi.org/10.1177/0047287513497837.

Lin, C.P., Tsai, Y.H., and Chiu, C.K. (2009). Modeling customer brand loyalty from an integrative perspective of self-determination theory and expectation-confirmation theory. Journal of Business and Psychology, 24(3), 315-326. https://doi.org/10.1007/s10869-009-9110-8.

Magatef, S.G. and Tomalieh, E.F. (2015). The impact of customer brand loyalty programs on customer retention. International Journal of Business and Social Science, 6(8), 78-93.

McDaniel, S.W. and Burnett, J.J. (1990). Customer religiosity and retail store evaluative criteria. Journal of the Academy of Marketing Science, 18(2), 101-112. https://doi.org/10.1007/BF02726426. 
Minton, E.A., Johnson, K.A., and Liu, R.L. (2019). Religiosity and special food consumption: The explanatory effects of moral priorities. Journal of Business Research, 95, 442-454. https://doi.org/10.1016/j.jbusres.2018.07.041.

Minton, E.A., Kahle, L.R., and Kim, C.H. (2015). Religion and motives for sustainable behaviors: A cross-cultural comparison and contrast. Journal of Business Research, 68(9), 1937-1944. https://doi.org/10.1016/j.jbusres.2015.01.003.

Mittelstaedt, J.D. (2002). A framework for understanding the relationships between religions and markets. Journal of Macromarketing, 22(1), 6-18. https://doi.org/10.1177/027467022001002.

Mokhlis, S. (2020). Customer religiosity and shopping behavior in Malaysia. Malaysian Management Journal, 11(1-2), 87-101.

Moschis, G.P., Mathur, A., and Sthienrapapayut, T. (2020). Gerontographics and customer behavior in later life: Insights from the life course paradigm. Journal of Global Scholars of Marketing Science, 30(1), 18-33. https://doi.org/10.1080/21639159.2019.1613908.

Nelissen, R.M., and Meijers, M.H. (2011). Social benefits of luxury brands as costly signals of wealth and status. Evolution and Human Behavior, 32(5), 343-355. https://doi.org/10.1016/j.evolhumbehav.2010.12.002.

Nurhayati, T. and Hendar, H. (2019). Personal intrinsic religiosity and product knowledge on halal product purchase intention. Journal of Islamic Marketing, 1-10. https://doi.org/10.1108/JIMA-11-2018-0220.

Nwankwo, S., Hamelin, N., and Khaled, M. (2014). Customer values, motivation, and purchase intention for luxury goods. Journal of Retailing and Customer Services, 21(5), 735-744. https://doi.org/10.1016/j.jretconser.2014.05.003.

Ozgen, O. and Esiyok, E. (2020). Customer ethics, materialism, and material satisfaction: A study on Turkish adolescent customers. International Journal of Customer Studies, 44(1), 14-24. https://doi.org/10.1111/ijcs.12541.

Pace, S. (2014). Effects of intrinsic and extrinsic religiosity on attitudes toward products: Empirical evidence of value-expressive and social-adjustive functions. Journal of Applied Business Research, 30(4), 1227-1238. https://doi.org/10.19030/jabr.v30i4.8668.

Paprzycka, E., Polec, W., and Mianowska, E. (2020). Religiosity as a (Non-) Necessary and (Non-) Sufficient Condition for the Permanence of Marriage. Conditions for the Decision to Divorce in Poland. Journal of Divorce \& Remarriage, 61(2), 105-126. https://doi.org/10.1080/10502556.2019.1627151.

Rahman, A.A., Asrarhaghighi, E., and Ab Rahman, S. (2015). Customers and Halal cosmetic products: knowledge, religiosity, attitude, and intention. Journal of Islamic Marketing, 6(1), 148-163. https://doi.org/10.1108/JIMA-09-2013-0068.

Razmus, W., Jaroszyńska, M., and Palęga, M. (2017). Personal aspirations and brand engagement in self-concept. Personality and Individual Differences, 105, 294-299.

https://doi.org/10.1016/j.paid.2016.10.018.

Reio Jr, T.G. and Shuck, B. (2015). Exploratory factor analysis: implications for theory, research, and practice. Advances in Developing Human Resources, 17(1), 12-25. https://doi.org/10.1177/1523422314559804.

Richins, M.L. and Dawson, S. (1992). A customer values orientation for materialism and its measurement: Scale development and validation. Journal of Customer Research, 19(3), 303-316. https://doi.org/10.1086/209304. 
Salam, M.T., Muhamad, N., and Leong, V.S. (2019). Measuring religiosity among Muslim customers: observations and recommendations. Journal of Islamic Marketing, 10(2), 633-652. https://doi.org/10.1108/JIMA-02-2018-0038.

Stavrianea, A. and Kamenidou, I. Religion in the context of economic crisis: The generation's perspective. Religion, 21(22), 23-68.

Tripathi, G. (2017). Customer satisfaction and word of mouth intentions: testing the mediating effect of customer brand loyalty. Journal of Services Research, 17(2), 1-16.

Truong, Y., McColl, R., and Kitchen, P.J. (2010). Uncovering the relationships between aspirations and luxury brand preference. Journal of Product and Brand Management, 19(5), 346-355. https://doi.org/10.1108/10610421011068586.

Ustaahmetoğlu, E. (2020). The influence of different advertisement messages and levels of religiosity on attitude and purchase intention. International Journal of Islamic and Middle Eastern Finance and Management, 1-19. https://doi.org/10.1108/IMEFM-02-2019-0064.

Uysal, A. and Okumuş, A. (2019). Impact of religiosity on ethical judgment: a study on the preference of retail stores among customers. Journal of Islamic Marketing, 10(4), 1332-1350. https://doi.org/10.1108/JIMA-07-2018-0131.

Vitell, S.J., Singh, J.J., and Paolillo, J.G. (2007). Customers' ethical beliefs: The roles of money, religiosity, and attitude toward business. Journal of Business Ethics, 73(4), 369-379. https://doi.org/10.1007/s10551-006-9212-4.

White, C. (2015). The impact of motivation on customer satisfaction formation: a self-determination perspective. European Journal of Marketing, 49(11/12), 1923-1940. https://doi.org/10.1108/EJM-08-2014-0501.

Wilcox, K., Kim, H.M., and Sen, S. (2009). Why do customers buy counterfeit luxury brands? Journal of Marketing Research, 46(2), 247-259. https://doi.org/10.1509/jmkr.46.2.247.

Xixiang, S., Gilal, R.G., and Gilal, F.G. (2016). Brand experience as a contemporary source of brand equity in the 21st century: evidence from the Chinese customer market. International Journal of Education and Research, 4(9), 63-76.

Zhang, N., Gong, Z.X., Xu, Z., and Gilal, F.G. (2019). Ethical climate and service behaviors in nurses: The moderating role of employment type. Journal of Advanced Nursing, 75(9), 1868-1876. https:// doi.org/10.1111/jan.13961. 